\title{
HOW MUCH OF THE LOCAL KNOWLEDGE ABOUT MEDICINAL PLANTS IS INCLUDED IN PUBLIC HEALTH POLICIES? A CASE STUDY FROM SOUTH BRAZIL
}

\author{
QUANTO DO CONHECIMENTO LOCAL SOBRE PLANTAS MEDICINAIS ESTÁ NAS POLÍTICAS PÚBLICAS DE \\ SAÚDE? UM ESTUDO DE CASO NO SUL DO BRASIL
}

\author{
Mariana GIRALDI ${ }^{1 *}$; Mel Simionato MARQUES ${ }^{1}$; Mara Rejane RITTER ${ }^{2}$; Natalia HANAZAKI ${ }^{1}$
}

Submitted 03/05/2016; Accept 11/10.2016; Published 31/10/2016

\begin{abstract}
The incorporation of traditional medicine in public health policies has been proposed by the World Health Organization (WHO). In Brazil this is reflected in RENISUS, an official list of medicinal plants of interest to the public health care system, with medicinal potential. Despite being an advance, this list reveals only a fraction of the biological and cultural diversity of Brazil. Using ethnobotanical data from two rural communities in Southern Brazil (Sertão do Ribeirão and Costa da Lagoa, Florianópolis municipality) we compared the RENISUS list with the lists of medicinal plants traditionally used. The similarity between the ethnobotanical lists was $26.32 \%$, and between RENISUS and each ethnobotanical list was less than $5 \%$. These results indicate the need to broaden the approach of the public health policies. The systematization of ethnobotanical data can be an interesting strategy for it.
\end{abstract}

KEYWORDS: ethnobotany, Jaccard similarity coefficient, pharmacopoeias, RENISUS, traditional medicine

\section{RESUMO}

A incorporação da medicina tradicional em sistemas públicos de saúde tem sido proposta pela Organização Mundial de Saúde (OMS). No Brasil isso se reflete na RENISUS, uma lista oficial de plantas medicinais de interesse ao sistema público de saúde, com potencial medicinal. Apesar de ser um avanço, essa lista reflete apenas uma fração da diversidade biológica e cultural do Brasil. Utilizando dados etnobotânicos de duas comunidades rurais no Sul do Brasil (Sertão do Ribeirão e Costa da Lagoa, município de Florianópolis) nós comparamos a lista RENISUS com listas de plantas medicinais usadas tradicionalmente. A similaridade entre as listas de plantas medicinais foi de $26.32 \%$, e entre a RENISUS com cada lista etnobotânica foi menor que $5 \%$. Esses resultados indicam a necessidade de uma abordagem mais ampla para as políticas públicas de saúde. A sistematização de dados etnobotânicos pode ser uma estratégia interessante para isso.

PALAVRAS-CHAVE: etnobotânica, coeficiente de similaridade de Jaccard, farmacopéias, RENISUS, medicina traditional

\footnotetext{
${ }^{1}$ Laboratory of Human Ecology and Ethnobotany, Ecology and Zoology Department, Federal University of Santa Catarina, ECZ-CCB-UFSC,

Florianópolis, SC 88010-970, Brazil; *e-mail: mariana_giraldi13@yahoo.com.br

${ }^{2}$ Federal University of Rio Grande do Sul, Department of Botany, Porto Alegre, Rio Grande do Sul, Brazil
} 


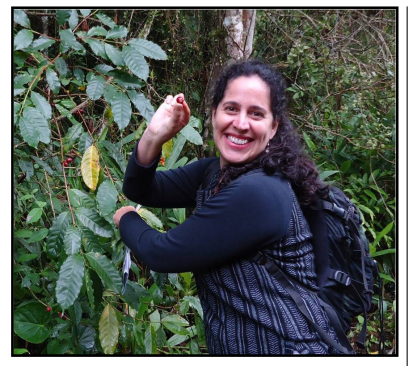

Mariana Giraldi is a Biologist graduated at UFSC and M.SC. in Botany at UFRPE. She researched Ethnobotany (medicinal and edible plants) with emphasis in Livelihoods and Food Security. Currently, she is a Biology teacher in the public basic education in the state of Santa Catarina, Brazil.

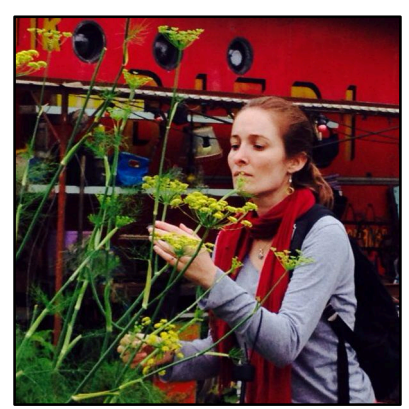

Mel Simionato Marques is a Biologist and M.Sc. in Plant Biology graduated UFSC. She focused her research in Ethnobotany, knowledge and use of plant resources. Bilingual teacher for children, with a an Environmental Education approach.

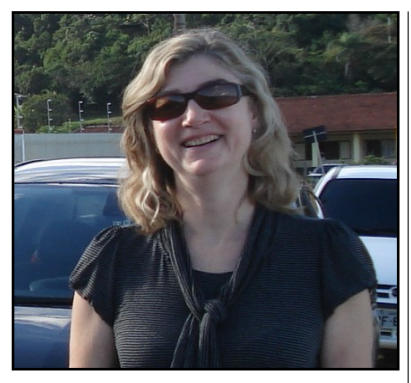

Mara Rejane Ritter is a Biologist graduated, M.Sc. and Ph.D. in Botany at UFRGS. Professor of Botany and Ethnobotany at UFRGS. Areas of expertise: Taxonomy of Angiosperm and Ethnobotany.

\section{INTRODUCTION}

The role of local knowledge and healing practices are increasingly recognized as complementary to biomedicine (CALVET-MIR et al., 2008; ZANK and HANAZAKI, 2012; GRUCA et al. 2014), and tentatively incorporated into different public health systems (e.g.: STANGELAND et al., 2008; CHAUDHARY and SINGH, 2011). In accordance with the principles of Traditional Medicine Strategy of the World Health Organization (2002) the Brazilian Government approved a National Policy on Medicinal Plants and Herbal Medicines (CORRÊA et al., 2006) and since 2009 adopted a list of plants with phytotherapeutic interest, known as RENISUS (National List of Medicinal Plants for the Public Health Care System). This list includes plants with use for health care by Brazilians and plants with known medicinal properties, and is the basis to incorporate medicinal plants and herbal medicines into the public health care system (BRASIL, 2013). Although this initiative was a step forward in terms of public policies, the list could more accurately reflect the biological and cultural diversity within the country. Ethnobotanical studies can contribute to this proposal, considering the great focus on medicinal plants in this area. Until 2007, 67\% of the published ethnobotanical papers in Brazil focused on medicinal plants (OLIVEIRA et al., 2009). The registration of local knowledge, indicating plants that comprise local pharmacopoeias, can be a rich source of information of plants that could be further included into RENISUS, reflecting the biological and cultural dimensions of knowledge and practices. In this scenario, the objective of this study was to reinforce the role of ethnobotany in defining public health policies to overcome the limitations of RENISUS in a local perspective, using ethnobotanical data from two communities from Southern Brazil as a case study. The RENISUS list is connected with the National Program of Medicinal Plants and Phytotherapics, which promote and recognize traditional practices in the use of medicinal plants. We expect a higher similarity between the studied communities, when compared with the RESINUS list, and if this hypothesis is supported we expect to show how the RENISUS list can be improved when taking into account the vast ethnobotanical repertoire about medicinal plants in Brazil.

\section{METHODOLOGY}

We calculated the similarity between three lists of medicinal plants two ethnobotanical survey lists and RENISUS. The ethnobotanical surveys were done in traditional communities from Santa Catarina Island, which are: Sertão do Ribeirão (GIRALDI and HANAZAKI, 2010) and Costa da Lagoa/Canto dos Araçás. Data from Costa da Lagoa/Canto 
dos Araçás were collected after prior informed consent (Authorization 651/10 of the Ethics Committee for Research with Human Beings of Federal University of Santa Catarina). We applied semi-structured interviews, including a free list of the medicinal plants known and used. The collaborators were sampled using the snowball method, with the inclusion criteria of being people who used medicinal plants as their curative practices, and resulted in 30 individual interviews. The two lists were compared to 63 species from RENISUS although RENISUS has 71 medicinal plant topics, it does not correspond to 71 species since in some cases each topic indicates more than one species or only a genera. Data from the three lists were reviewed for synonyms and taxonomy. We excluded from the analysis cases with taxonomic uncertainties (e.g.: we had Cucurbita pepo L. in one list and Cucurbita sp. in other list, then we decided to exclude both plants from the analysis because it could be or not the same species). We considered 69 medicinal plants at Costa da Lagoa/Canto dos Araçás, 89 at Sertão do Ribeirão and the plants from RENISUS. We used The Plant List (2016) database to check scientific names. Collected plants were deposited at FLOR Herbarium (Federal University of Santa Catarina) and at the EAFM Herbarium (Federal Institute of Education, Science and Technology of Amazonas). We used Jaccard similarity coefficient (VALENTIN, 2000) to compare the presences and absences of species among the three lists.

\section{RESULTS AND DISCUSSION}

The similarity between the Costa da Lagoa/Canto dos Araçás list and RENISUS was 4.35\% ( $\mathrm{Sj}=0.0435)$, between the Sertão do Ribeirão list and RENISUS was $4.55 \%$ $(S j=0.0455)$; between the ethnobotanical studies was $26.32 \%(\mathrm{Sj}=0.2632)$ and between all lists was $19.75 \%(\mathrm{Sj}=0.1975)$

(Figure 1). The remaining $45.05 \%$ referred to exclusive plants from the lists.

The ethnobotanical lists are more similar to each other than when compared with RENISUS - the similarity between each list with RENISUS is considerably lower. It is important to remember that Jaccard similarity coefficient allows comparisons within data sets. For

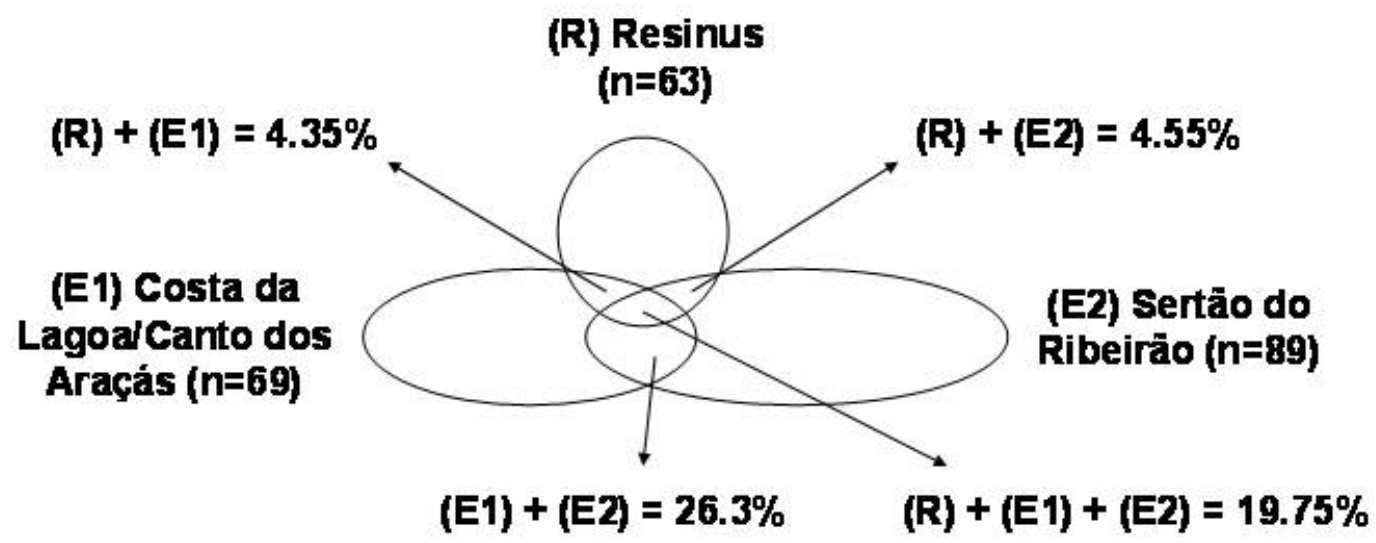

Figure 1: Diagram ilustrating the similarity of medicinal plants listed at Costa da Lagoa/Canto dos Araçás (E1) ( $n=29$ interviews), Sertão do Ribeirão (E2) ( $n=13$ interviews) and RENISUS (R) 
example, Campos and Ehringhaus (2003) compared the local knowledge of palms used by indigenous and non-indigenous communities in the Amazon and found the Jaccard values relatively low - between $\mathrm{Sj}=0.326$ and $\mathrm{Sj}=0.588$ for general uses and between $\mathrm{Sj}=0.189$ and $\mathrm{Sj}=0.341$ for specific uses. Ladio and Lozada (2003) compared the similarity of edible plants in two Mapuche communities from Patagonia, Argentina, finding some similarity of knowledge $(S j=0.450)$ and use $(S j=0.461)$. De Boer et al. (2012) compared medicinal plant knowledge in three human groups from Lao, obtaining values ranging from $\mathrm{Sj}=0.44$ to $\mathrm{Sj}=0.75$, which were considered quite low since the groups share the same ecological area and have the same dependence on medicinal plants.

The similarities found in the present study were regarded as low. The low similarity between the ethnobotanical lists is an indicative of the variation in local knowledge about medicinal plants in Santa Catarina Island, and the need for further studies. The even lower similarity between RENISUS and each ethnobotanical list (less than 5\%) indicate gaps to be filled in RENISUS to reach a more faithful reality of Brazilian medicinal plants traditionally used. A total of 25 medicinal plants common to the communities of Costa da Lagoa/Canto dos Araçás and Sertão do Ribeirão (Table 1) were not listed in RENISUS. This result may not be meaningful for the North and Northeast regions of Brazil - as there are other environments and cultural influences - but may it be for the Azoreans along the Southern coast. Brazil has a great biological diversity and a large amount of human groups with diverse knowledge associated with natural resources. Understandably, this biodiversity could hardly be summed up in a single national panorama.

Table 1. Common species of medicinal plants from RENISUS (R) and the ethnobotanical lists at Costa da Lagoa/Canto dos Araçás (E1) and Sertão do Ribeirão (E2)

\begin{tabular}{|c|c|c|}
\hline Family & Specie & Similarity \\
\hline AMARYLLIDACEAE & Allium sativum $\mathrm{L}$. & common to 3 lists \\
\hline APIACEAE & Foeniculum vulgare Mill. & common to 3 lists \\
\hline ASPARAGACEAE & Aloe vera (L.) Burm. f. & common to 3 lists \\
\hline ASTERACEAE & Achillea millefolium $\mathrm{L}$. & common to 3 lists \\
\hline ASTERACEAE & Artemisia absinthium L. & common to 3 lists \\
\hline ASTERACEAE & Bidens pilosa $\mathrm{L}$. & common to 3 lists \\
\hline ASTERACEAE & Cynara cardunculus subsp. flavescens Wiklund & common to 3 lists \\
\hline ASTERACEAE & Gymnanthemum amygdalinum (Delile) Sch.Bip. ex Walp. & common to 3 lists \\
\hline ASTERACEAE & Matricaria chamomilla L. & common to 3 lists \\
\hline LAMIACEAE & Plectranthus barbatus Andrews & common to 3 lists \\
\hline LAURACEAE & Persea americana Mill. & common to 3 lists \\
\hline MYRTACEAE & Eugenia uniflora $\mathrm{L}$. & common to 3 lists \\
\hline MYRTACEAE & Psidium guajava $\mathrm{L}$. & common to 3 lists \\
\hline MYRTACEAE & Syzygium cumini (L.) Skeels & common to 3 lists \\
\hline PHYLLANTHACEAE & Phyllanthus tenellus Roxb. & common to 3 lists \\
\hline RUTACEAE & Ruta graveolens $\mathrm{L}$. & common to 3 lists \\
\hline ADOXACEAE & Sambucus australis Cham. \& Schltdl. & $\mathrm{E} 1+\mathrm{E} 2$ \\
\hline AMARANTHACEAE & Alternanthera brasiliana (L.) Kuntze & $\mathrm{E} 1+\mathrm{E} 2$ \\
\hline AMARYLLIDACEAE & Allium cepa $\mathrm{L}$. & $\mathrm{E} 1+\mathrm{E} 2$ \\
\hline APIACEAE & Pimpinella anisum $\mathrm{L}$. & $\mathrm{E} 1+\mathrm{E} 2$ \\
\hline ASTERACEAE & Calea sp. & $\mathrm{E} 1+\mathrm{E} 2$ \\
\hline ASTERACEAE & Cnicus benedictus L. & $\mathrm{E} 1+\mathrm{E} 2$ \\
\hline ASTERACEAE & Cyrtocymura scorpioides (Lam.) H.Rob. & $\mathrm{E} 1+\mathrm{E} 2$ \\
\hline ASTERACEAE & Sphagneticola trilobata (L.) Pruski & $\mathrm{E} 1+\mathrm{E} 2$ \\
\hline
\end{tabular}




\begin{tabular}{|c|c|c|}
\hline Family & Specie & Similarity \\
\hline ASTERACEAE & Tanacetum vulgare $\mathrm{L}$. & $\mathrm{E} 1+\mathrm{E} 2$ \\
\hline CARICACEAE & Carica papaya L. & $\mathrm{E} 1+\mathrm{E} 2$ \\
\hline COMMELINACEAE & Dichorisandra thyrsiflora J.C. Mikan & $\mathrm{E} 1+\mathrm{E} 2$ \\
\hline FABACEAE & Cajanus cajan (L.) Millsp. & $\mathrm{E} 1+\mathrm{E} 2$ \\
\hline FABACEAE & Zollernia ilicifolia (Brongn.) Vogel & $\mathrm{E} 1+\mathrm{E} 2$ \\
\hline LAMIACEAE & Lavandula angustifolia Mill. & $\mathrm{E} 1+\mathrm{E} 2$ \\
\hline LAMIACEAE & Melissa officinalis L. & $\mathrm{E} 1+\mathrm{E} 2$ \\
\hline LAMIACEAE & Plectranthus ornatus Codd & $\mathrm{E} 1+\mathrm{E} 2$ \\
\hline LAMIACEAE & Rosmarinus officinalis L. & $\mathrm{E} 1+\mathrm{E} 2$ \\
\hline LYTHRACEAE & Cuphea carthagenensis (Jacq.) J.F. Macbr. & $\mathrm{E} 1+\mathrm{E} 2$ \\
\hline MYRTACEAE & Psidium cattleyanum Sabine & $\mathrm{E} 1+\mathrm{E} 2$ \\
\hline MYRTACEAE & Syzygium aromaticum (L.) Merr. \& L.M. Perry & $\mathrm{E} 1+\mathrm{E} 2$ \\
\hline PHYTOLACCACEAE & Petiveria alliacea $\mathrm{L}$. & $\mathrm{E} 1+\mathrm{E} 2$ \\
\hline POACEAE & Cymbopogon citratus (DC.) Stapf & $\mathrm{E} 1+\mathrm{E} 2$ \\
\hline POLYGALACEAE & Polygala paniculata $\mathrm{L}$. & $\mathrm{E} 1+\mathrm{E} 2$ \\
\hline RUTACEAE & Citrus reticulata Blanco & $\mathrm{E} 1+\mathrm{E} 2$ \\
\hline THEACEAE & Camellia sinensis (L.) Kuntze & $\mathrm{E} 1+\mathrm{E} 2$ \\
\hline AMARANTHACEAE & Dysphania ambrosioides (L.) Mosyakin \& Clemants & $\mathrm{R}+\mathrm{E} 1$ \\
\hline CELASTRACEAE & Maytenus ilicifolia Mart. ex Reissek & $\mathrm{R}+\mathrm{E} 1$ \\
\hline LYTHRACEAE & Punica granatum $\mathrm{L}$. & $R+E 1$ \\
\hline APIACEAE & Petroselinum crispum (Mill.) Nyman ex A.W.Hill & $R+E 2$ \\
\hline BROMELIACEAE & Ananas comosus (L.) Merr. & $R+E 2$ \\
\hline ZINGIBERACEAE & Curcuma longa $\mathrm{L}$. & $R+E 2$ \\
\hline ZINGIBERACEAE & Zingiber officinale Roscoe & $R+E 2$ \\
\hline
\end{tabular}

\section{CONCLUSIONS}

There are no doubts that RENISUS represents an improvement for the Brazilian public health system, as well as representing a way to include ethnobotanical knowledge in public health policies. According to guidelines of the National Medicinal Plant and Herbal Medicine Policy of Brazil, the Ministry of Health should encourage the development of research centers on medicinal plants, with as one of its purposes the constant update of RENISUS. The systematization of ethnobotanical data into state and/or regional levels could possibly give a better overview of the medicinal plants already known and used within the country. Different methods can be used to define which plants should be included into RENISUS, we used Jaccard similarity coefficient to give an example of what can be done to qualitatively compare ethnobotanical surveys.

\section{ACKNOWLEDGEMENTS}

This paper is the contribution number 08 supported by CAPES/PNADB through the project "Knowledge, use and conservation of plant biodiversity in Atlantic Forest and Caatinga" (UFSC/UFRPE/UFRGS). We thank CAPES for the master scholarships for MG and MSM and CNPq for a research productivity scholarship for $\mathrm{NH}$.

\section{REFERENCES}

Brasil 2013. Ministério da Saúde. Available in: http://portal.saude.gov.br/portal/saude/profissiona I/visualizar_texto.cfm?idtxt $=30780$. Access in $2^{\text {nd }}$ May 2016.

CALVET-MIR, L. et al. Is there a divide between local medicinal knowledge and Western medicine? A case study among native Amazonians in Bolivia. Journal of Ethnobiology and Ethnomedicine, v. 4, n. 18, p. 1-11, 2008.

CAMPOS, M. T.; EHRINGHAUS, C. Plant virtues are in the eyes of the beholders: a comparision of known palm uses among indigenous and folk 
communities of southwestern Amazonia. Economic Botany, v. 57, n. 3, p. 324-344, 2003.

CHAUDHARY, A.; SINGH, N. Contribution of world health organization in the global acceptance of Ayurveda. Journal of Ayurveda and Integrative Medicine, v. 2: p. 179-186, 2011.

CORRÊA, A. P. R. et al. (orgs.) Política Nacional de Plantas Medicinais e Fitoterápicos. Brasília: Ministério da Saúde, 2006. Available in http://bvsms.saude.gov.br/bvs/publicacoes/politica nacional_fitoterapicos.pdf. Access in: $\underline{2}^{\text {nd }}$ May 2016.

DE BOER, H. J. et al. Comparing medicinal plant knowledge using similarity indices: a case of the Brou, Saek and Kry in Lao PDR. Journal of Ethnopharmacology, v. 141: p. 481-500, 2012.

GIRALDI, M.; HANAZAKI, N. Uso e conhecimento tradicional de plantas medicinais no Sertão do Ribeirão, Florianópolis/SC, Brasil. Acta Botânica Brasilica, v. 24, p. 395-406, 2010.

GRUCA, M. et al. New categories for traditional medicine in the Economic Botany Data Collection Standard. Journal of Ethnopharmacology, v. 155, p. 1388-1392, 2014.

LADIO, A. H.; LOZADA, M. Comparision of wild edible plant diversity and foraging strategies in two aboriginal communities of northwestern Patagonia. Biodiversity and Conservation, v. 12, p. 937-951, 2003.

MARQUES, M. S. Plantas de uso medicinal nas comunidades da Costa da Lagoa e Canto dos Araçás, Florianópolis. SC: retrato de dois momentos. 2010. 63p. Trabalho de Conclusão de Curso (Graduação em Ciências Biológicas) - Universidade Federal de Santa Catarina, Florianópolis, 2010.

OLIVEIRA, F. C. et al. Avanços nas pesquisas etnobotânicas no Brasil. Acta Botânica Brasilica, v. 23, p. 590-605, 2009.

Relação Nacional de Plantas Medicinais de Interesse ao Sistema Único de Saúde (RENISUS) 2009. Available in: http://portal.saude.gov.br/portal/arquivos/pdf/REN ISUS.pdf, access in May 2013.

STANGELAND, $T$. et al. Recognition and development of traditional medicine in Tanzania. Journal of Ethnopharmacology, v. 117, p. 290-299, 2008.

The Plant List. Available in: http://www.theplantlist.org/. Access in: $2^{\text {nd }}$ May 2016.

VALENTIN, J. L. Ecologia Numérica: uma introdução à análise multivariada de dados ecológicos. Rio de Janeiro: Interciência, 2000.

World Health Organization (WHO) 2002. Traditional Medicine Strategy 2002-2005. Available in:

http://apps.who.int/iris/bitstream/10665/67163/1/ WHO_EDM_TRM_2002.1.pdf, access in May 2013.

ZANK, S.; HANAZAKI, N. Exploring the links between ethnobotany, local therapeutic practices, and protected areas in Santa Catarina coastline, Brazil. Evidence-based Complementary and Alternative Medicine, v. 2012, p. 1-15, 2012. 